Supplement of Biogeosciences, 13, 3757-3776, 2016

http://www.biogeosciences.net/13/3757/2016/

doi:10.5194/bg-13-3757-2016-supplement

(C) Author(s) 2016. CC Attribution 3.0 License.

(c) (i)

Supplement of

\title{
Combining livestock production information in a process-based vegeta- tion model to reconstruct the history of grassland management
}

Jinfeng Chang et al.

Correspondence to: Jinfeng Chang (jinfeng.chang@ locean-ipsl.upmc.fr)

The copyright of individual parts of the supplement might differ from the CC-BY 3.0 licence. 


\section{Supplementary Information}

\section{Text S1. Specific grazing strategy for wild herbivores}

In prehistoric times, wild animals were distributed all over the world. Now, along with the development of civilization and especially the population growth after the industrial revolution, the habitats of wild animals have been mostly cultivated as cropland and pasture. Nowadays, wild animals can only exist on sparsely populated land (e.g., high latitude region such as Siberia, and Amazonian forest) or reserves (e.g., reserves in African savanna). Significant population of wild herbivores living on grassland can only be found in North America, Scandinavia, the former USSR and Africa (Bouwman et al., 1997). Nevertheless, wild herbivores are estimated to eat $3 \%-10 \%$ of the consumable NPP where they exist (Warneck, 1988). They thus contribute to the GHG balance of grassland. Unlike domestic ruminants fed by harvested forage, crop products and/or by-products during the non-growing season, wild herbivores stay on grassland all year round. To simulate the grazing of wild herbivores, a specific grazing strategy was introduced in ORCHIDEE-GM v3.1. We assumed that: 1) during growing season when grass biomass is sufficient to support grazing, unit of wild herbivores (converted to Livestock Unit, LU) will eat the same amount of fresh grass biomass as domestic ruminants (e.g., with daily metabolisable energy (ME) requirement of ca. $85 \mathrm{MJ} \mathrm{LU}^{-1}$ day $^{-1}$ and intake of $18 \mathrm{~kg} \mathrm{DM} \mathrm{LU}^{-1}$ day $^{-1}$; see Chang et al., 2015a for detail); 2) during the non-growing season when fresh grass biomass is insufficient, wild herbivores will eat dead grass instead (with daily intake of $10 \mathrm{~kg} \mathrm{DM} \mathrm{LU}^{-1} \mathrm{day}^{-1}$ given the unpalatability of dead grass). The dead grass is defined as fresh litter from grass biomass only, excluding the litter from excreta of grazing animals.

\section{Text S2. Domestic ruminant stocking density and its historical changes}

FAOSTAT (2014) provides annual country-averaged statistical data for dairy cows, beef cattle, sheep and goats of livestock numbers (with the unit in head). The gridded livestock of the world (GLW) (Wint and Robinson 2007) uses environmental variables to spatially distribute national data down to grid-level. Recently, an improved database using sub-national data (Gridded Livestock of the World v2.0, Robinson et al., 2014) has been generated, and was first corrected to match the polygon values of the observed data and then to match the FAOSTAT country values in 2006.

Feed requirements for an animal may differ significantly for different species across countries. For facilitating cross-country comparison by taking into account all categories of livestock, FAO (2003) presents the conversion factors for major livestock categories that take into account "feed requirements" for the animal. However, the conversion factors provided by FAO (2003) only contain values for 11 regions of the world, and cannot represent the within-regional (country-specific) variation. To obtain a more consistent and realistic ruminant stocking density, livestock species in GLW v2.0 are converted here to livestock unit (LU) based on the calculation of metabolisable energy (ME) requirement for each country (see Supporting Information of Chang et al., 2015a for details). In this study, $\mathrm{ME}$ requirement, the amount of energy $\left(\mathrm{MJ} \mathrm{day}^{-1}\right)$ an animal needs for maintenance and for 
activities such as lactation, and pregnancy, were calculated following the IPCC Tier 2 algorithms (IPCC, 2006 Vol 4, Chapter 10, Eqs. 10.3 to 10.13). One LU is defined as an average adult dairy cow producing $3000 \mathrm{~kg}$ milk annually, with live body weight of $600 \mathrm{~kg}$ (Eurostat, 2013; with ME requirement of ca. $85 \mathrm{MJ} \mathrm{day}^{-1}$, and with dry matter intake of ca. $18 \mathrm{~kg}$ daily, calculated in Supporting Information Text S1 of Chang et al., 2015a). The conversion factor (F) for livestock category $i$ (i.e., cattle, sheep or goats) in country $j$ is calculated as:

$$
F_{i, j}=\frac{M E_{\text {head }, i, j}}{M E_{L U}}
$$

where $M E_{L U}$ (unit: $\mathrm{MJ} \mathrm{yr}^{-1} \mathrm{LU}^{-1}$ ) is the ME requirement by one $\mathrm{LU}$; and $M E_{\text {head,i,j }}$ (unit: $\mathrm{MJ} \mathrm{yr}^{-1}$ head $^{-1}$ ) is the ME requirement per head of livestock category $i$ in country $j$, given by:

$$
M E_{\text {head }, i, j}=\frac{M E_{i, j}}{N_{\text {animal }, i, j}}
$$

where $N_{\text {animal }, i j}$ (unit: head) is the total number (in head from FAOSTAT) of animals in livestock category $i$ in country $j ; M E_{i, j}$ (unit: $\mathrm{MJ} \mathrm{yr}^{-1}$ ) is the total ME requirement of livestock category $i$ in country $j$, which includes the ME of animals for different production types (i.e., animals producing milk, slaughtered for meat, or animals neither producing milk nor slaughtered for meat; see Supporting Information Text S1 of Chang et al., 2015a for details). To be consistent with the country-level livestock data used by GLW v2.0, statistical data (FAOSTAT, 2014) for the reference year 2006 were used to calculate the conversion factors.

For each grid-cell $k$ in country $j$, the ruminant density of category $i$ for the reference year $2006\left(D_{\text {ref } f, j, j}\right)$ can be calculated as:

$$
D_{r e f, i, j, k}=D_{G L W, i, k} \quad F_{i, j}
$$

where $D_{G L W, i, k}$ is the original density of livestock category $i$ in grid-cell $k$ from GLW v2.0 dataset (with original unit head per square $\mathrm{km}$ of suitable areas in livestock production systems; Robinson et al., 2011). To be consistent with the spatial resolution of climate forcings used to drive global vegetation models, the category-specific ruminant stocking density $\left(D_{G L W, i, k}\right)$ was aggregated from the original resolution (about $1 \times 1 \mathrm{~km}$ at the Equator) to $0.5^{\circ} \times 0.5^{\circ}$ (about $50 \times 50 \mathrm{~km}$ at the Equator) considering suitable areas in livestock production systems (Robinson et al., 2011), and was then converted to the unit of LU per hectare of land area in each grid-cell (Fig. S1).

Domestic ruminant numbers, and therefore stocking density, are continually changing from year-toyear as reported in FAOSTAT (2014). However, GLW v2.0 only provides livestock density for the reference year (i.e., 2006). To establish the historic changes of ruminant density from 1901 to 2012, two assumptions were made: 1) the distribution of ruminant density did not change during the timespan of this study (1901 - 2012); and 2) the changes in the ruminant density of each category in gridcell $k$ in country $j\left(D_{m, j, k}\right)$ co-varied with the changes in category-specific ME requirement in that country. Thus the total ruminant density for grid-cell $k$ in country $j$ in year $m\left(D_{m, j, k}\right.$, with the unit of LU per ha of land area) is calculated as: 


$$
D_{m, j, k}=\left(D_{r e f, i, j, k} \frac{M E_{m, i, j}}{M E_{r e f, i, j}}\right)
$$

where $D_{\text {ref } f, j, k}$ is the ruminant density of category i for grid-cell k in country $\mathrm{j}$ in reference year (i.e., 2006); $M E_{m, i, j}$ and $M E_{\text {ref } f, j}$ (the units of them: $M J \mathrm{yr}^{-1}$ ) are the total ME requirement by ruminant category $\mathrm{i}$ for country $\mathrm{j}$ in year $\mathrm{m}$ and in the reference year 2006 respectively. The method to calculate

ME requirement is given in Supporting Information Text S1 of Chang et al., 2015a. Here, the range of year $\mathrm{m}$ is from 1961 to 2012, since FAOSTAT (2014) provides annual country-averaged statistical data for dairy cows, beef cattle, sheep and goats of livestock numbers (unit: head), and meat (carcass weight) or milk yield for the period from 1961 up to the present day.

For the period 1900-1960, regional livestock numbers by 10-year interval derived from Mitchell (1993, 1998a, b) were scaled in 1961 to match the FAOSTAT data (data processed by Dr. Kees Klein Goldewijk, and given for 17 world regions with the numbers of cattle, sheep and goats; available in the HYDE database: http://themasites.pbl.nl/tridion/en/themasites/hyde/landusedata/livestock/index2.html). The 17 world regions were designated for global change research, as defined by Kreileman et al. (1998). Linear interpolation is applied to calculate the regional livestock numbers of each year. Assuming the meat (carcass weight) and milk yield for the period of 1900-1960 are the same as that for 1961 from FAOSTAT (2014), total ruminant stocking density for grid-cell $k$ in region $q$ in year $m$ $\left(D_{m, p, k}\right)$ is then simply extended to $1900-1960$ through:

$$
D_{m, q, k}=\left(D_{r e f, i, q, k} \frac{M E_{m, i, q}}{M E_{r e f, i, q}}\right)
$$

where $D_{\text {refi,i, }, k}$ is the ruminant density of category i for grid-cell $\mathrm{k}$ in region $q$ in reference year (i.e., 2006); $M E_{m, i, q}$ and $M E_{r e f, i, q}$ are the total ME requirement by ruminant category i for region $q$ in year $\mathrm{m}$ and in the reference year 2006 respectively.

Text S3. The historic land-cover change maps

25 The historic land-cover change maps were based on GLC2000 land-cover data (Bartholomé and Belward, 2005; Eva et al., 2004) as reference map for the year 2000. To be used by global vegetation models like ORCHIDEE-GM, GLC2000 land-cover data were aggregated to $0.5^{\circ} \times 0.5^{\circ}$, and grouped into plant functional types (PFT) using the reclassification method from Poulter et al. (2011). The fraction of cropland in the PFT map was further constrained by the cropland area of 2000 in the HYDE 3.1 dataset (Klein Goldewijk et al., 2011). The above processes produced a reference GLC2000-based PFT map for the year 2000. The land-use changes derived from Hurtt et al. (2011) were applied to this reference PFT map to constrain the land-cover changes of forest, grassland (combining pasture and natural grassland), and cropland during the period 1901-2005. As a result, a set of historic PFT maps suitable for global vegetation models were established distinguishing global land-cover changes for the period of 1901-2005. However, note that management types of grassland (e.g., mown, grazed or unmanaged) are not separated in these historic PFT maps. 


\section{Text S4. Wild herbivore density maps}

Gridded maps of wild herbivore density were derived from the population data for larger herbivores shown in the literature and collected by Bouwman et al. (1997; also see Table S2 for details). The populations of these larger herbivores were first converted to LU (according to the metabolisable energy (ME) requirement calculated based on mean weight; Table S2), and then distributed to suitable grassland based on grassland aboveground (consumable) NPP simulated from ORCHIDEE-GM. Here the suitable grassland in each grid-cell is defined by a set of rules. For North America, Scandinavia, and the former USSR where moose and reindeer are major wild herbivores, the suitable grassland $\left(A_{\text {wild-suit }}\right)$ is the unmanaged grassland in the grid-cell where: 1) grassland fraction is over 10\%;2) the fraction of unmanaged (extensive) grassland is over 70\%; 3) forest fraction is over 40\%; and 4) human population density is lower than 50 capita $\mathrm{km}^{-2}$. For Africa where bovids are mainly grazing on savanna, the suitable grassland is grassland in the grid-cell where: 1) grassland fraction is over 20\%;2) the fraction of unmanaged (extensive) grassland is over 50\%; and 3) human population density is lower than 50 capita $\mathrm{km}^{-2}$. Assuming higher consumable NPP supports more wild herbivores, the wild herbivore density for grid-cell $k$ in region $q\left(D_{\text {wild, }, k}\right)$ is calculated as:

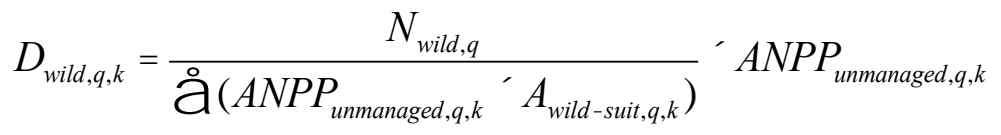

where $N_{\text {wild, } q}$ is the population of larger herbivores in region $q$ (unit: LU) derived from Bouwman et al. (1997) and converted to LU; $A N P P_{\text {unmanaged, }, \text {, }}$ is the aboveground NPP of unmanaged (extensive)

grassland simulated by O RCHIDEE-GM v3.1 averaged for the period of 1971-1990; $A_{\text {wild-suit, }, k \text { is }}$ is the corresponding suitable grassland area of grid cell $k$. For Africa, median population of bovids (300 million head) was used for density distribution, given the estimated population range (100 - 500 million head; Van Soest et al., 1994; McDowell 1976; Table S2). The resultant wild herbivore density (Fig. S2) is assumed to be constant during the period of 1901-2012 because no population data were available.

\section{Text S5. Mineral and organic fertilizer applications over grassland and their historical changes}

In order to establish the gridded organic (manure) fertilizer application rate for countries/regions other than EU-27, we use the animal manure-N fertilizers on grasslands for 17 world regions at 1995 derived from various sources (e.g., IFA, 1999; FAO/IFA/IFDC, 1999; FAO/IFA, 2001) and synthesized by Bouwman et al. (2002a; also see Table S3 for detail). Note that animal manure-N was estimated as all excretion from cattle, pigs, and poultry, except that part excreted during grazing, use of manure as fuel, and storage losses of $\mathrm{NH}_{3}$ (Bouwman et al., 2002a). 
To downscale the total amount of regional $\mathrm{N}$ fertilizer to grid-level (except for OECD Europe and Eastern Europe where gridded data are available), the rules suggested by Bouwman et al. (2002b) are used, namely: animal manure application to grasslands is assumed to occur in mixed farming systems that are defined as grasslands occurring in grid-cells where the arable land coverage exceeds $35 \%$ in developed countries and $15 \%$ in developing countries. Here, the grasslands that satisfy the above rules are cited as manure-suitable grassland $\left(A_{\text {manure-suit,ref, }, k}\right)$. In addition, assuming higher ruminant density produces more manure, we calculate the manure- $\mathrm{N}$ application rate for grid-cell $k$ in region $q$ in manure data reference year $1995\left(N_{\text {manure, } r e f, q, k}\right)$ as:

$$
N_{\text {manure,ref, },, k}=\frac{Q_{\text {manure, } q}}{\left(D_{\text {ref }, q, k} A_{\text {manure suit }, \text { ref }, q, k}\right)} D_{\text {ref }, q, k}
$$

10 where $Q_{\text {manure } q}$ is the total amount of manure-N fertilizer in region $q$ from Bouwman et al., (2002a, b); $A_{\text {manure-suit,ref,q, }}$ is the manure-suitable grassland area for grid-cell $k$ in region $q$; and $D_{r e f, q, k}$ is the total domestic ruminant stocking density (including cattle, sheep and goats from the maps established in Text S1) for grid-cell $k$ in region $q$ where manure-suitable grassland exists.

Given the assumption that higher ruminant density produces more manure, the manure fertilizer application rate $\left(N_{\text {manure }}\right)$ is assumed to change along with changes in the total ruminant stocking density. It is calculated as:

$$
N_{\text {manure }, m, k}=N_{\text {manure, } r e f, k} \frac{D_{m, k}}{D_{\text {ref }, k}}
$$

where $N_{\text {manure, } m, k}$ and $N_{\text {manure, ref }, k}$ is the manure $\mathrm{N}$ application rate for grid-cell $k$ in year $m$ and manure application data reference year 1995 respectively; $D_{m, k}$ and $D_{r e f, k}$ are the total domestic ruminant stocking density (from the maps established in Text S1) in grid-cell $\mathrm{k}$ in year $\mathrm{m}$ and manure application data reference year 1995 respectively.

For mineral-N fertilizers on grassland, country-scale data of fertilized area and mean fertilization rate $\left(N_{\text {mineral }}\right)$ for 1999/2000 are available in FAO/IFA/IFDC/IPI/PPI (2002) with grassland/pasture been fertilized in 34 countries. Within the 34 countries, 21 of them belong to EU-27 where gridded fertilizer application rate is available. For the other 13 non-EU-27 countries, the fertilized areas are given indicating that not all the grassland is fertilized. Thus the national mean application rates are applied on grid-cells with a total ruminant stocking density above a certain threshold. The value of this threshold is determined for each country making the total grassland area of fertilized grids is identical to the national fertilized grassland area reported by FAO/IFA/IFDC/IPI/PPI (2002). However, note that the regional total amount of mineral-N fertilizer aggregated from country-scale data in FAO/IFA/IFDC/IPI/PPI (2002) is much lower than the values given in Bouwman et al. (2002a; see Table S3 for detail).

The temporal evolution of gridded mineral-N fertilization for the EU-27 has been described by Chang et al. (2015a) for the period 1901-2010. For the other 13 countries, the country-scale total nitrogenous fertilizer consumption data $\left(Q_{\text {mineral }}\right)$; derived from FAOSTAT, 2014; available for the period 19612002) were used to extrapolate the mineral-N application rate $\left(N_{\text {mineral }}\right)$. For Azerbaijan and Belarus, where FAOSTAT only provide data for 1992-2002, the variation of nitrogenous fertilizer consumption 
by the former USSR is used for the period 1961-1991. The rate of mineral-N application for grid-cell $k$ in year $m$ in country $j\left(N_{\text {mineral,m,j,k }}\right)$ changes along with the variation of country-scale $Q_{\text {mineral }}$, and is calculated as:

$$
N_{\text {mineral }, m, j, k}=N_{\text {mineral }, r e f, j, k} \frac{Q_{m, j}}{Q_{r e f, j}}
$$

5

where $N_{\text {mineral,ref, } k}$ is the mineral-N application rate for grid-cell $k$ in mineral application data reference year 2000, which is given by FAO/IFA/IFDC/IPI/PPI (2002); $Q_{m, j}$ and $Q_{2000, j}$ are the country-scale total nitrogenous fertilizer consumption in country $j$ in year $m$ and in mineral application data reference year 2000 respectively. The mineral-N fertilization rate after 2002 is taken as constant and the same as that in 2002. For the period 1901-1960, the same set of rules as applied for the EU-27 (see section 'Simulation set-up' in Chang et al., 2015a for details) are used: 1) no mineral-N fertilizer was applied over grassland before 1950; and 2) For the period 1951-1961, the rate of application is assumed to increase linearly from zero to the level of 1961.

Text S6. Sun-induced chlorophyll fluorescence (SIF) data processing

A global SIF dataset was produced using spectra from the Global Ozone Monitoring Experiment-2 (GOME-2) instrument onboard the MetOp-A platform (Joiner et al., 2013). In this study, daily SIF retrievals from 2007 to 2012 are aggregated to monthly values (Version 26 (V26), Level 3 products with the spatial resolution of $0.5^{\circ} \times 0.5^{\circ}$ ) and averaged for each month to produce a mean seasonal variation related to photosynthetic activity. The seasonal variation of SIF is normalized (with the mean value $=1$ ) to evaluate the seasonality of grassland GPP simulated by ORCHIDEE-GM v3.1. In the GOME-2 SIF pixels that have a ground footprint of $\sim 40 \mathrm{~km}$ by $80 \mathrm{~km}$ at nadir view during the time period examined, different PFTs can co-exist in the same grid-cell with different phenologies — this could bias the seasonality of grassland GPP. To reduce the contamination of SIF by non-grassland PFTs, we restrict the model-data comparison to grassland-dominated grid-cells, defined as those with grassland cover in the MOD12Q1 dataset (Sect. 2.5.2) is larger than $50 \%$.

Originally, SIF-GPP is calculated by SIF-GPP $=-0.10+3.72 \times$ SIF (V14) as given by Guanter et al. 30 (2014) based on comparisons with cropland and grassland flux tower sites in the northern hemisphere at middle latitudes. However, SIF data V26 used in this study differs somewhat in magnitude from V14 used by Guanter et al. (2014). To obtain the SIF-GPP linear model for SIF V26, we performed a linear regression between SIF V26 and SIF V14 monthly data over the fourteen grid cells that encompass the flux towers used in Table S1 of Guanter et al. (2014) and for the same time period. The resultant relationship obtained, is SIF-V14 $=1.25 \times$ SIF-V26 $(r=0.96)$. The linear model SIF-GPP $=$ $0.1+4.65 \times \operatorname{SIF}(\mathrm{V} 26)$ is used to calculate SIF-GPP in this study. 
Reference:

Crutzen, P. J., Heidt, L. E., Krasnec, J. P., Pollock, W. H. and Seiler, W.: Biomass burning as a source of atmospheric gases $\mathrm{CO}, \mathrm{H}_{2}, \mathrm{~N}_{2} \mathrm{O}, \mathrm{NO}, \mathrm{CH}_{3} \mathrm{Cl}$ and COS. Nature, 282, 253-256, 1979.

Dietze, M. C., Serbin, S. P., Davidson, C., Desai, A. R., Feng, X., Kelly, R., Kooper, R., LeBauer, D., Mantooth, J. and McHenry, K.: A quantitative assessment of a terrestrial biosphere model's data needs across North American biomes. J. Geophys. Res. Biogeosci., 119, 286-300, 2014.

Domingues, T. F., Meir, P., Feldpausch, T. R., Saiz, G., Veenendaal, E. M., Schrodt, F., Bird, M., Djagbletey, G., Hien, F. and Compaore, H.: Co-limitation of photosynthetic capacity by nitrogen and phosphorus in West Africa woodlands. Plant Cell Environ., 33, 959-980, 2010.

Drew, K. and Baskin, L.: Wildlife production systems: economic utilisation of wild ungulates, 469 pp., Cambridge Univ. Press, New York, 1989.

Eurostat: http://epp.eurostat.ec.europa.eu/statistics_explained/index.php/Glossary:LSU， (last access: December 2013), 2013.

Ghannoum, O., Evans, J. R., Chow, W. S., Andrews, T. J., Conroy, J. P. and von Caemmerer, S.: Faster Rubisco is the key to superior nitrogen-use efficiency in NADP-malic enzyme relative to NAD-malic enzyme C4 grasses. Plant Physiol., 137, 638-650, 2005.

IPCC (Intergovernmental Panel on Climate Change): 2006 IPCC Guidelines for National Greenhouse Gas Inventories, Prepared by the National Greenhouse Gas Inventories Programme, Eggleston H.S., Buendia L., Miwa K., Ngara T. and Tanabe K. (Eds), IGES, Hayama, Japan, 2006.

Joiner, J., Guanter, L., Lindstrot, R., Voigt, M., Vasilkov, A., Middleton, E., Huemmrich, K., Yoshida, Y. and Frankenberg, C.: Global monitoring of terrestrial chlorophyll fluorescence from moderate-spectral-resolution near-infrared satellite measurements: methodology, simulations, and application to GOME-2. Atmos. Meas. Tech., 6, 2803-2823, 2013.

Kowalczyk, E., Stevens, L., Law, R., Dix, M., Wang, Y., Harman, I., Haynes, K., Srbinovsky, J., Pak, B. and Ziehn, T.: The land surface model component of ACCESS: description and impact on the simulated surface climatology. Aust. Meteorol. Oceanogr. J., 63, 65-82, 2013.

Kreileman, E., Van Woerden, J. and Bakkes, J.: RIVM Environmental Research. CIM Rep. M025, 98, 1998.

McDowell, R.: Importance of ruminants of the world for non-food uses. Cornell University, New York, 1976.

Niinemets, Ü.: Research review. Components of leaf dry mass per area-thickness and density-alter leaf photosynthetic capacity in reverse directions in woody plants. New Phytol., 144, 35-47, 1999.

Niinemets, Ü.: Global-scale climatic controls of leaf dry mass per area, density, and thickness in trees and shrubs. Ecology, 82, 453-469, 2001.

35 Robinson, T., Thornton, P., Franceschini, G., Kruska, R., Chiozza, F., Notenbaert, A., Cecchi, G., Herrero, M., Epprecht, M., Fritz, S., You, L., Conchedda, G. and See, L.: Global livestock production systems. Food and Agriculture Organization of the United Nations (FAO), Rome, 152 pp., 2011.

Van Soest, P. J.: Nutritional ecology of the ruminant: Cornell University Press, 1994. 
Whitley, R. J., Macinnis-Ng, C.M.O., Hutley, L. B., Beringer, J., Zeppel, M., Williams, M., Taylor, D. and Eamus, D.: Is productivity of mesic savannas light limited or water limited? Results of a simulation study. Global Change. Biol., 17, 3130-3149, 2011.

Wint, G. and Robinson, T.: Gridded livestock of the world 2007. Rome: Food and Agricultural Organization of the United Nations. Animal Production and Health Division, 131 pp, 2007.

Yue, X. and Unger, N.: The Yale Interactive terrestrial Biosphere model version 1.0: description, evaluation and implementation into NASA GISS ModelE2. Geosci. Model Dev., 8, 2399$2417,2015$.

Zeppel, M., Macinnis-Ng, C., Palmer, A., Taylor, D., Whitley, R., Fuentes, S., Yunusa, I., Williams, M. and Eamus, D.: An analysis of the sensitivity of sap flux to soil and plant variables assessed for an Australian woodland using a soil-plant-atmosphere model. Funct. Plant Biol., 35, 509-520, 2008. 


\section{Supplementary Tables and Figures}

Table S1. The maximum rate of rubisco carboxylation activity at a reference temperature of $25^{\circ} \mathrm{C}$

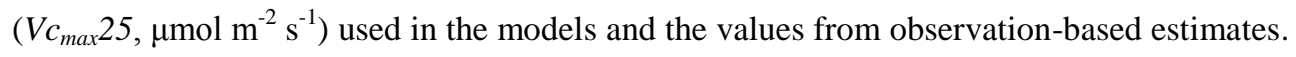

\begin{tabular}{llll}
\hline \multirow{2}{*}{ Model } & \multicolumn{2}{c}{$V c_{\max } 25\left(\mu \mathrm{mol} \mathrm{m}^{-2} \mathrm{~s}^{-1}\right)$} & \\
\cline { 2 - 4 } & $\mathrm{C} 3$ grass & $\mathrm{C} 4$ grass & Reference \\
\hline ORCHIDEE-GM & 55 & 25 & Chang et al., 2013; this study \\
Yale Interactive terrestrial & 43 & 24 & Yue and Unger, 2015 \\
$\begin{array}{l}\text { Biosphere model (YIB) } \\
\text { PEcAn/ED model }\end{array}$ & 58 & 21 & Dietze et al., 2014 \\
ACCESS-CABLE & 60 & 10 & Kowalczyk et al., 2013 \\
Soil-plant-atmosphere (SPA) & 73.6 & 47 & Whitley et al., 2011; data \\
model & & & colleted from Zeppel et al., \\
& & & 2008; Ghannoum et al., 2005 \\
\hline Observation based estimate & & $15.2-25.6$ & Feng and Dietze, 2013 \\
\hline & $43.2-130.5$ & $21.7-46.3$ & Verheijen et al., 2013; data \\
& $24.4-118.4$ & & collected from Domingues et \\
& & & al., 2010; Kattge et al., 2009; \\
& & & Niinemets, 1999, 2001 \\
\hline
\end{tabular}


Table S2. The population of wild herbivores in the world ${ }^{\mathrm{a}}$.

\begin{tabular}{|c|c|c|c|c|c|c|c|}
\hline & North & & Former & & & Mean weight & ME requirement (MJ \\
\hline Wild Herbivores & America & Scandinavia & USSR & Africa & Source & $(\mathrm{kg})^{\mathrm{b}}$ & day $\left.^{-1}\right)^{\mathrm{c}}$ \\
\hline \multicolumn{8}{|l|}{ Moose (Million } \\
\hline head) & 0.9 & 0.6 & 1 & & Drew and Baskin, 1989 & 350 & 50 \\
\hline \multicolumn{8}{|l|}{ Reindeer (Million } \\
\hline head) & 16.5 & 0.8 & 2.7 & & Drew and Baskin, 1989 & 90 & 13 \\
\hline Bovids (Million & & & & & Van Soest et al., 1994; & & \\
\hline head) & & & & $100-500$ & McDowell 1976 & 125 & 18 \\
\hline \multicolumn{8}{|l|}{ Total (Million } \\
\hline LU) & 3.1 & 0.5 & 1 & $21-106$ & & 600 & 85 \\
\hline
\end{tabular}

${ }^{a}$ Data were derived from literature and collected by Bouwman et al. (1997).

${ }^{b}$ The mean weight of wild herbivores were derived from Crutzen et al. (1986). For mean weight of Bovids in Africa, the weight of wildebeest was used.

${ }^{c}$ The metabolisable energy (ME) requirement of 1 LU was calculated following the IPCC Tier 2 algorithms (IPCC, 2006 Vol 4, Chapter 10, Eqns 10.3 to 10.13), and

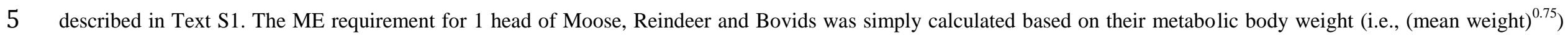
and the ratio between their metabolic body weight and that for $1 \mathrm{LU}$, given the facts that: 1) net energy (NE) for maintenance (NEm) is the major part of total ME, and calculated based on the metabolic body weight; 2) Some other parts of ME, such as NE for activity, for pregnancy, and for draft power (looking for food), are directly correlated to NEm. 
Table S3. Animal manure-N and mineral-N fertilizers on grasslands for 17 world regions at 1995 synthesized by Bouwman et al. (2002a), and the mineral-N fertilizers on grasslands at 1999/2000 derived from FAO/IFA/IFDC/IPI/PPI (2002).

\begin{tabular}{|c|c|c|c|}
\hline Region Name & $\begin{array}{r}\text { Animal manure-N } \\
\text { (1000 tonne) }\end{array}$ & $\begin{array}{r}\text { Mineral-N } \\
\text { (1000 tonne) }\end{array}$ & $\begin{array}{r}\text { Mineral-N (1000 tonne; } \\
\text { FAO/IFA/IFDC/IPI/PPI, 2002) }\end{array}$ \\
\hline$\overline{\text { Canada }}$ & 207 & 0 & $\overline{0}$ \\
\hline USA & 1583 & 0 & 0 \\
\hline Central America & 351 & 25 & 3 \\
\hline South America & 1051 & 12 & 77 \\
\hline Northern Africa & 34 & 0 & 17 \\
\hline Western Africa & 137 & 0 & 0 \\
\hline Eastern Africa & 148 & 0 & 0 \\
\hline Southern Africa & 78 & 31 & 26 \\
\hline OECD Europe & 3085 & 3074 & 2616 \\
\hline Eastern Europe & 737 & 210 & 46 \\
\hline Former USSR & 2389 & 760 & 135 \\
\hline Middle East & 167 & 17 & 0 \\
\hline South Asia & 425 & 0 & 0 \\
\hline East asia & 1404 & 0 & 0 \\
\hline South East Asia & 477 & 0 & 0 \\
\hline Oceania & 52 & 175 & 75 \\
\hline Japan & 59 & 27 & 102 \\
\hline World & 12386 & 4331 & 3097 \\
\hline
\end{tabular}


Table S4. Fertilized area, average mineral-N fertilizer application rate, total mineral-N fertilizer used over grassland, the threshold of ruminant density and the corresponding grassland area for the 13 nonEU countries. Fertilized area, average mineral-N fertilizer application rate, and the total mineral-N fertilizer for 1999/2000 were derived from FAO/IFA/IFDC/IPI/PPI (2002). The threshold of ruminant density was chosen to make total fertilized grassland area be similar to the fertilized area given by FAO/IFA/IFDC/IPI/PPI (2002).

\begin{tabular}{|c|c|c|c|c|c|}
\hline Name & $\begin{array}{r}\text { Fertilized area } \\
\qquad(1000 \mathrm{ha})\end{array}$ & $\begin{array}{l}\text { Fertilized rate } \\
\qquad\left(\mathrm{kg} \mathrm{N} \mathrm{ha}^{-1}\right)\end{array}$ & $\begin{array}{l}\text { Total } \mathrm{N} \text { fertilizer } \\
\text { (1000 tonne })\end{array}$ & $\begin{array}{l}\text { Threshold } \\
\left(\mathrm{LU} \mathrm{ha}^{-1}\right)\end{array}$ & $\begin{array}{r}\text { Fertilized Area } \\
\text { above threshold } \\
\text { (1000 ha) }\end{array}$ \\
\hline Australia & 30000 & 2.5 & 75.0 & 0.10 & 29730 \\
\hline Azerbaijan & 54 & 6.0 & 0.3 & 0.31 & 141 \\
\hline Belarus & 2405 & 40.0 & 96.2 & 0.15 & 2743 \\
\hline Chile & 900 & 45.0 & 40.5 & 0.29 & 916 \\
\hline Dominican Republic & 13 & 80.0 & 1.0 & 0.70 & 152 \\
\hline Japan & 965 & 106.0 & 102.3 & 0.36 & 1023 \\
\hline Mexico & 20 & 80.0 & 1.6 & 0.63 & 113 \\
\hline Morocco & 341 & 51.0 & 17.4 & 0.23 & 365 \\
\hline Norway & 145 & 100.0 & 15.0 & 0.22 & 153 \\
\hline South Africa & 1750 & 15.0 & 26.3 & 0.24 & 1901 \\
\hline Switzerland & 360 & 45.0 & 16.0 & 0.23 & 381 \\
\hline Uruguay & 650 & 10.0 & 6.5 & 0.66 & 694 \\
\hline Venezuela & 600 & 50.0 & 30.0 & 0.75 & 701 \\
\hline
\end{tabular}


Table S5. The consumable NPP for wild herbivores and actual consumption simulated by ORCHIDEEGM v3.1.

North America $\quad$ Scandinavia Former USSR Africa World total

Consumable ANPP

(Million tonne DM)

431

21

711

$4614 \quad 5778$

Total consumption

(Million tonne DM)

14

2

$5 \quad 127-634^{*} \quad 147-654$

Portion $3 \%$

$9 \%$ $1 \% \quad 3 \%-14 \% \quad 3 \%-11 \%$

* The values for Africa come from the range of the Bovids population given in Table S2. 

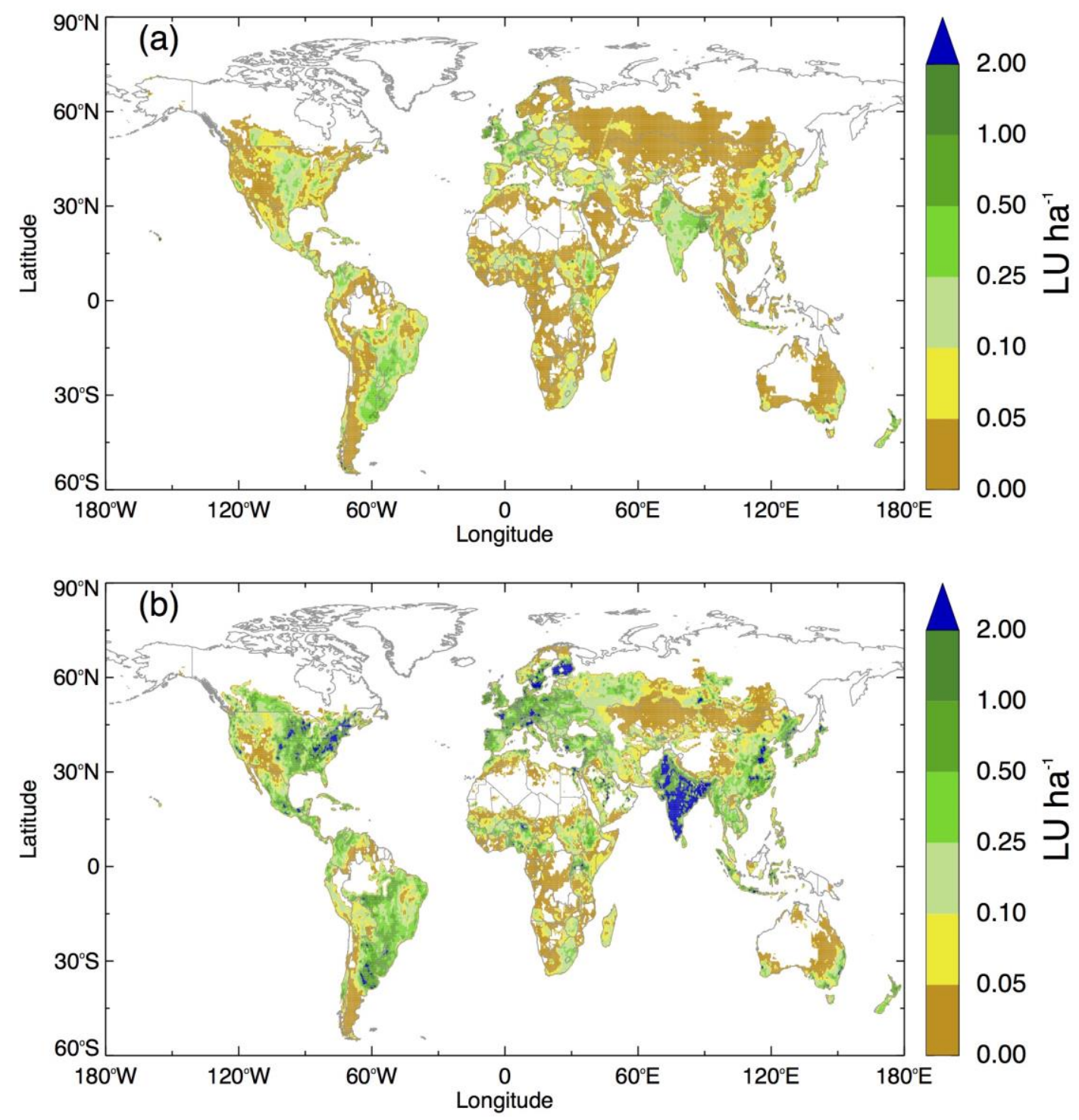

Figure S1. Domestic ruminant stocking density (a) and grazing-ruminant stocking density (b) of the world for the reference year 2006. Domestic ruminant stocking density data was derived from the Gridded Livestock of the World v2.0 (GLW v2.0; data on ruminants including cattle, sheep and goats were used; Robinson et al., 2014), converted to livestock unit (LU), and aggregated to the resolution of $0.5^{\circ} \times 0.5^{\circ}$ (see Supplementary Information Text S1 for details). Grazing-ruminant stocking density was calculated based on the domestic ruminant stocking density (Text S1) and the grassland area from the historic land-cover change maps (see Sect. 2.4 and Supplementary Information Text S2 for details). 


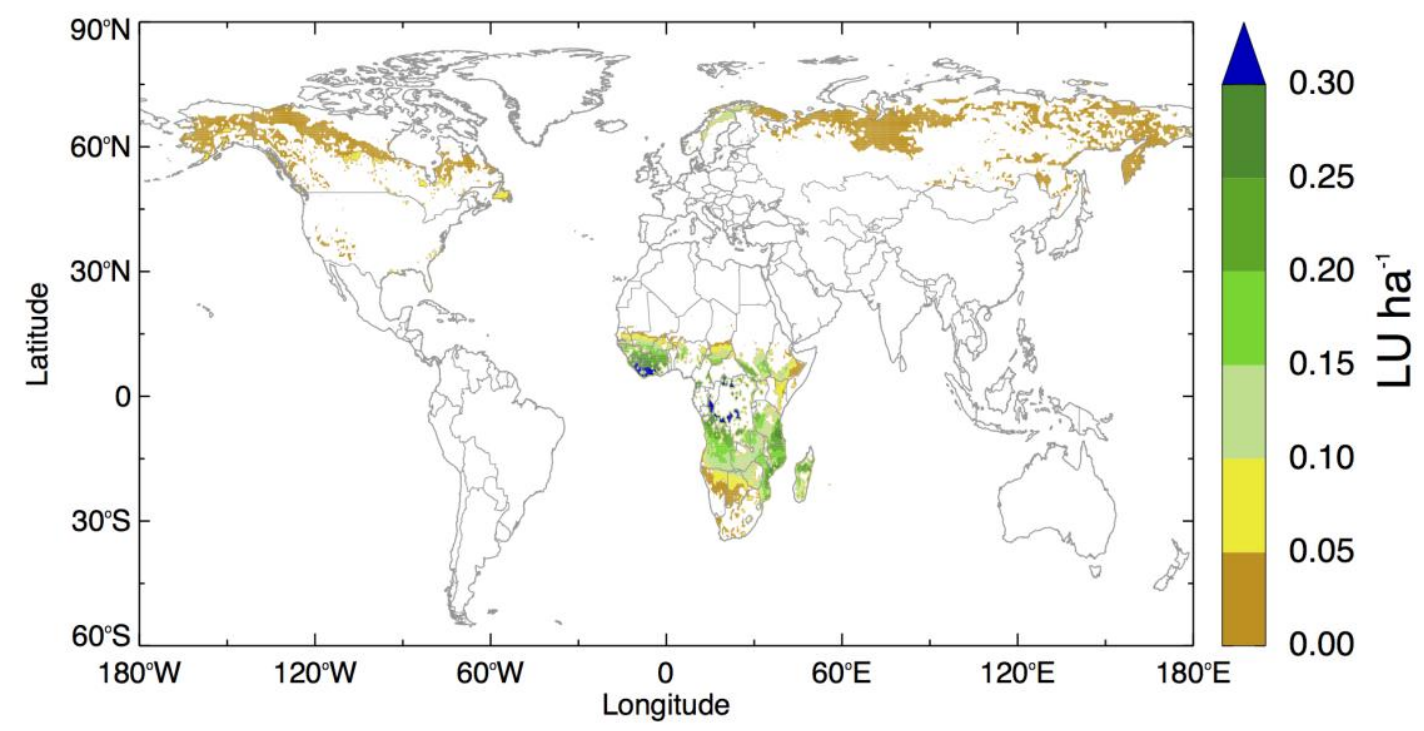

Figure S2. Wild herbivore density across the world. Original data from literature were collected by Bouwman et al. (1997), and shown in Table S2. The processes of map construction were described in the Supplementary Information Text S3.

5 

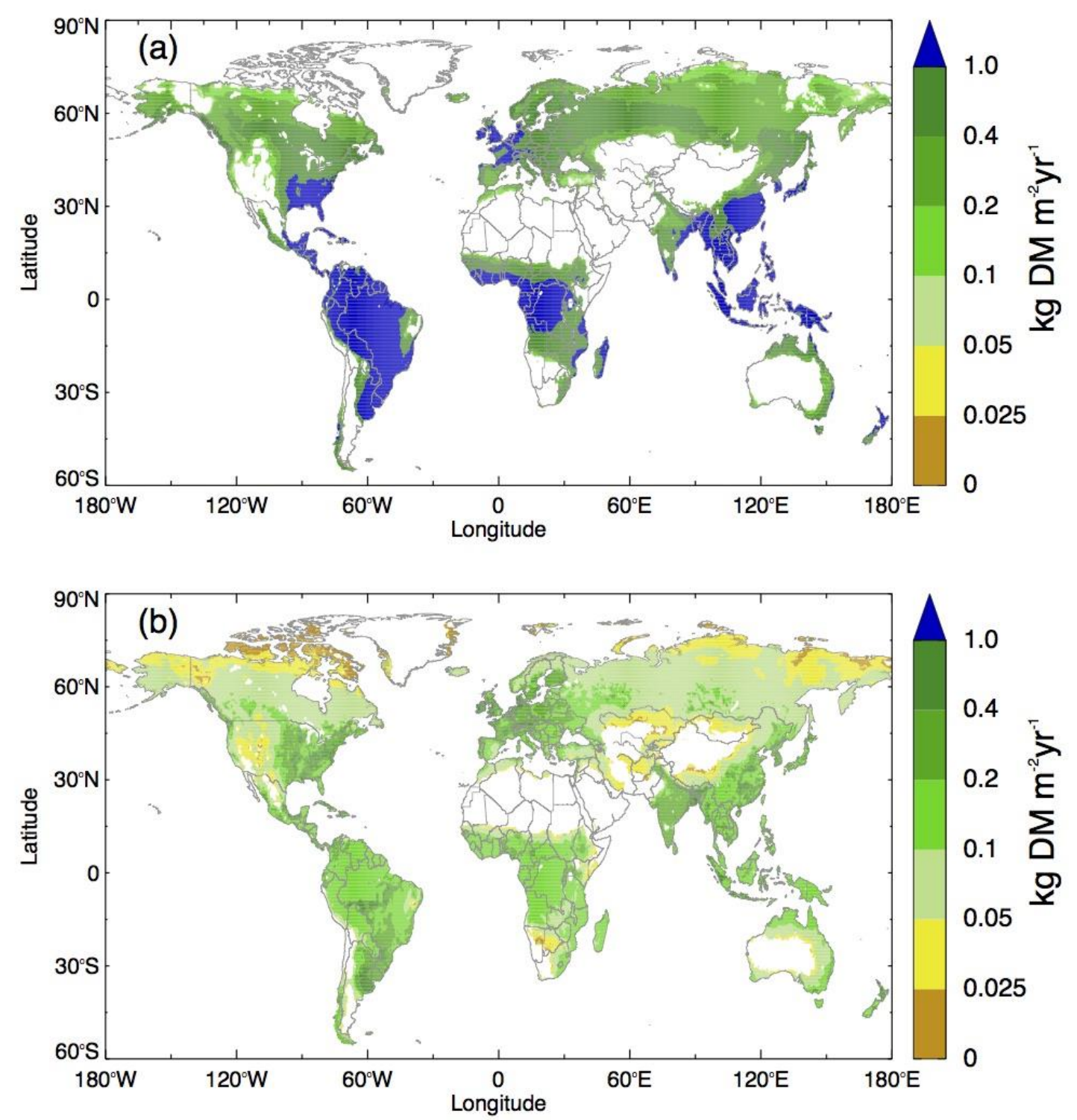

Figure S3. (a) The potential harvested biomass from mown grassland and (b) the potential biomass consumption over grazed grassland, simulated by ORCHIDEE-GM. Data were averaged for the period 1991-2010. The historic gridded grazing-ruminant stocking density used as input to ORCHIDEE-GM v3.1 was described in Sect. 2.4. It is noteworthy that a minimum grazing-ruminant density of $0.2 \mathrm{LU}$ $\mathrm{ha}^{-1}$ was set to drive the model given the fact that too low grazing-ruminant density is not economical in practice. 


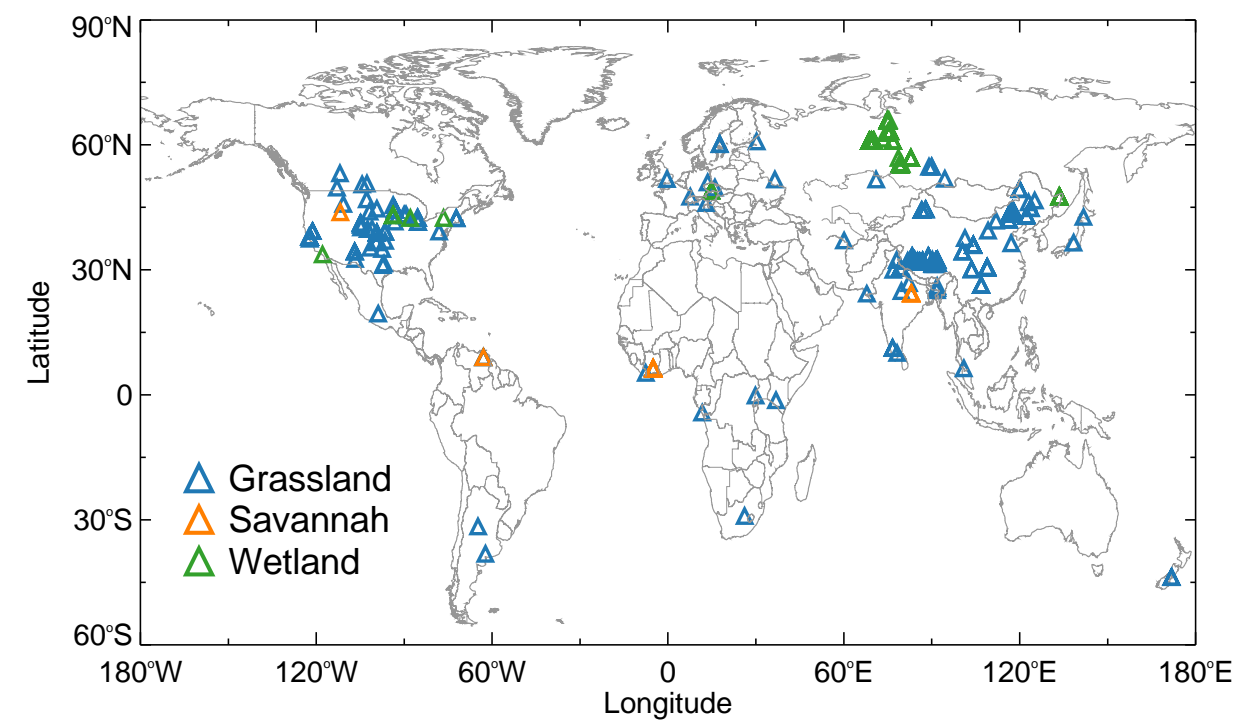

Figure S4. Spatial distribution of grassland NPP observations. In total, 270 NPP observations from 129 sites all over the world (including grassland, wetland and savanna) are used in this study. 


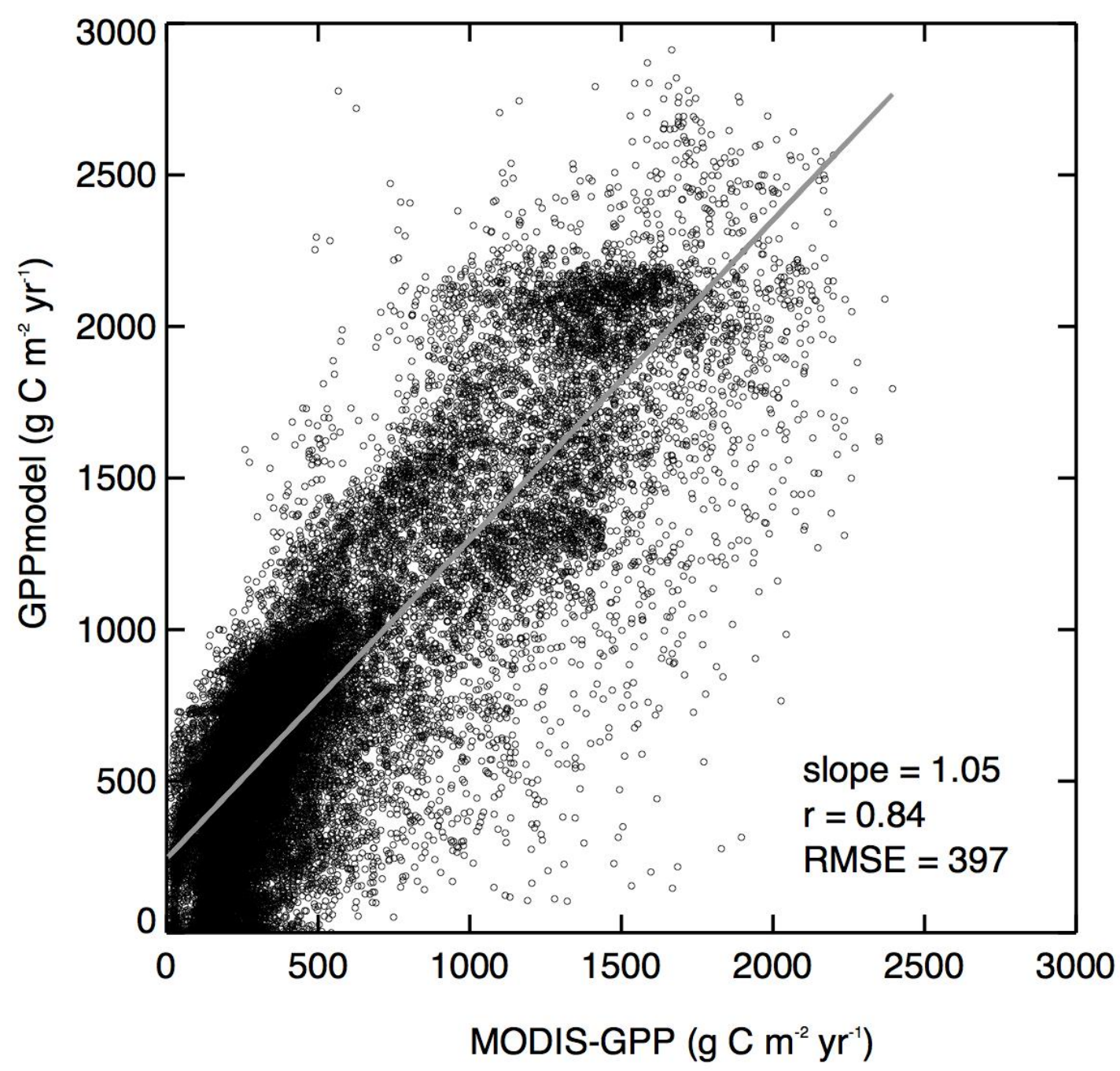

Figure S5. Comparison between MODIS-GPP and modelled GPP at the resolution of $0.5^{\circ} \times 0.5^{\circ}$. Gridcells with grassland covering more than $20 \%$ of total land (i.e., grassland is not a trivial land cover in that grid-cell) in the MOD12Q1 dataset are used. 

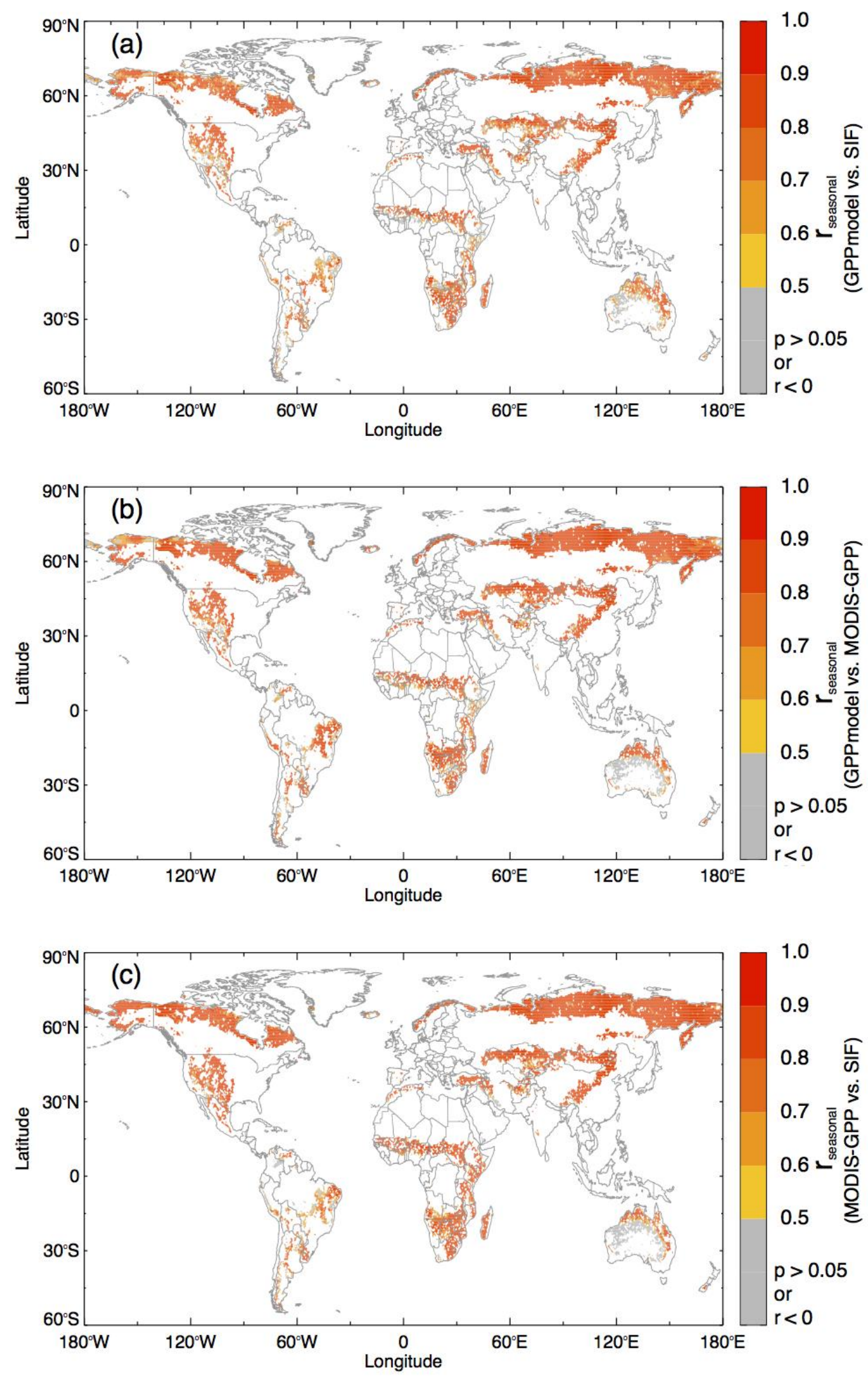
Figure S6. Spatial distribution of $r_{\text {seassonal }}$ between (a) SIF data and GPP $P_{\text {model }}$, (b) MODIS-GPP and $G P P_{\text {model }}$ and (c) MODIS-GPP and SIF data respectively. $r_{\text {seasonal }}$ is the correlation coefficient between mean seasonal cycle of modelled GPP, MODIS-GPP and SIF data from 2008 to 2012. This figure only shows the $r_{\text {seasonal }}$ for grid-cells with grassland covering more than 50\% of total land in the MOD12Q1

5 dataset. Grey colour indicates insignificant or negative $r_{\text {seasonal }}(\mathrm{p}>0.05$ or $\mathrm{r}<0)$; and yellow-to-red indicate significant positive $r_{\text {seasonal }}$ with increasing value $(\mathrm{r}>0$ and $\mathrm{p}<0.05)$. 